\title{
Proteomic identification of MYC2-dependent jasmonate-regulated proteins in Arabidopsis thaliana
}

\author{
Jing Guo ${ }^{1,2+}$, Qiuying Pang ${ }^{1,2+}$, Lihua Wang ${ }^{1}$, Ping Yư ${ }^{1}$, Nan $\mathrm{Li}^{1}$ and Xiufeng Yan ${ }^{1 *}$
}

\begin{abstract}
Background: MYC2, a basic helix-loop-helix (bHLH) domain-containing transcription factor, participates in the jasmonate $(J A)$ signaling pathway and is involved in the modulation of diverse JA functions. However, a comprehensive list of MYC2-dependent JA-responsive proteins has yet to be defined.
\end{abstract}

Results: In this paper, we report the comparative proteomics of wild-type (WT) plants and jin 1-9, a MYC2 mutant plant, in response to methyl jasmonate (MeJA) treatment. Proteins from mock/MeJA-treated jin 1-9 and WT samples were extracted and separated by two-dimensional gel electrophoresis. Twenty-seven JA-mediated proteins demonstrated differential expression modulated by MYC2. We observed that MYC2 negatively regulates the accumulation of JA-dependent indolic glucosinolate-related proteins and exhibits opposite effects on the biosynthetic enzymes involved aliphatic glucosinolate pathways. In addition, proteins involved in the tricarboxylic acid cycle and a majority of the MeJA-inducible proteins that are involved in multiple protective systems against oxidative stress were reduced in jin 1-9/myc2 sample compared to the WT sample. These results support a positive role for MYC2 in regulating JA-mediated carbohydrate metabolism and oxidative stress tolerance.

Conclusions: We have identified MYC2-dependent jasmonate-regulated proteins in Arabidopsis thaliana by performing two-dimensional gel electrophoresis and MALDI-TOF/TOF MS analysis. The observed pattern of protein expression suggests that MYC2 has opposite effects on the biosynthetic enzymes of indolic and aliphatic glucosinolate pathways and positively regulates JA-mediated carbohydrate metabolism and oxidative stress tolerance-related proteins. Furthermore, it is very interesting to note that MYC2 plays opposite roles in the modulation of a subset of JA-regulated photosynthetic proteins during short-term and long-term JA signaling. This study will enhance our understanding of the function of MYC2 in JA signaling in Arabidopsis thaliana.

Keywords: Arabidopsis thaliana, Jasmonate, MYC2, Proteomics

\section{Introduction}

Jasmonates (JAs), including jasmonate and methyl jasmonate (MeJA), are a group of plant growth regulators and signaling molecules derived from linolenic acid. They are well known because they have pivotal roles in many aspects of plant development such as root growth, senescence, fertility, production of secondary metabolites and responses to abiotic and biotic stresses [1-5].

\footnotetext{
* Correspondence: yanxiufeng@wzu.edu.cn

${ }^{\dagger}$ Equal contributors

'College of Life and Environmental Science, Wenzhou University, Wenzhou 325035, China

Full list of author information is available at the end of the article
}

To date, various genes involved in the JA signaling pathway have been identified. The CORONATINEINSENSITIVE1 (COI1) gene, which is a JA receptor, encodes an F-box protein [6,7]. COI1 combines with Skp1-like 1, Skp1-like 2, cullin 1, and ring-box protein 1 to form an E3 ubiquitin ligase known as the $\mathrm{SCF}^{\mathrm{COI}}$ complex [8-10], which promotes the ubiquitination and degradation of the repressors of the JA signaling pathway. The JA ZIM-domain (JAZ) proteins (JAZ1 to JAZ12) that share a conserved ZIM and Jas motif are targets of the $\mathrm{SCF}^{\mathrm{CO} 1}$ complex; therefore, they act as negative regulators of the JA-responsive genes [11-16]. Recently, it was demonstrated that a co-receptor complex consisting of COI1, JAZ, and inositol pentakisphosphate

\section{() Biomed Central}


strongly binds to (+)-7-iso-JA-Ile and therefore functions as the jasmonate receptor [17]. In addition, three closely related basic helix-loop-helix (bHLH) domain-containing transcription factors (TFs), MYC2, MYC3, and MYC4, interact with JAZs to mediate JA responses [18-20].

MYC2 is the most well-known and studied MYC isoform and is involved in JA signaling. $M Y C 2$ is allelic to the JAI1/JIN1 (JASMONATE-INSENSITIVE1) locus and binds to the G-box and derived sequences in the promoter regions of JA-induced genes [11,21-23]. All three MYC proteins showed highest binding affinity to a canonical G-box, whereas MYC2 and MYC3 were undistinguishable, MYC4 showed lower affinity for the G-box variants [19]. It has been established that MYC3 and MYC4 act in concert with MYC2 during the activation of JA responses, including JA-induced expression of VSP2 [19]. In a recent study, by performing microarray analysis on the jin1 mutant, it was demonstrated that MYC2 regulates the expression of a considerable number of JA-responsive genes, including the genes involved in JA-induced indolic glucosinolate and auxin biosynthesis, and those related to oxidative stress tolerance, and insect herbivory resistance [22]. However, the proteins regulated by MYC2 at the protein level remain to be elucidated.

In the present study, the effect of MeJA on the jin1-9/ $m y c 2$ and WT Arabidopsis thaliana (Arabidopsis) proteome was assessed by two-dimensional gel electrophoresis (2-DE) and MS/MS analysis. The main objectives of this study were to identify proteins that were differentially expressed in the mock and MeJA-treated jin1-9/ $m y c 2$ and WT samples and to elucidate the role of MYC2 in JA signaling pathway. A list of MYC2-dependent JAresponsive proteins was obtained, and this will enhance our understanding of the function of MYC2 in JA signaling in Arabidopsis.

\section{Results and discussion}

Identification of MYC2-dependent JA-regulated proteins by $2-\mathrm{DE}$ and $\mathrm{MS} / \mathrm{MS}$

To investigate the role of MYC2 in JA-regulated gene expression at the posttranscriptional level, three-weekold WT and jin1-9/myc2 mutant plants were treated with $200 \mu \mathrm{M}$ MeJA or mock solution, and a 2-DE strategy was used to analyze protein expression changes in response to short-term $(6 \mathrm{~h})$ and long-term $(48 \mathrm{~h}) \mathrm{MeJA}$ treatment. The short-term time point was chosen based on previously published Arabidopsis cDNA microarray reports, which demonstrated that the expression of a large number of genes was significantly altered by MeJA-treatment for $6 \mathrm{~h}$ [22]. We hypothesized that gene expression at the transcriptional level may not correlate well with that observed at the protein level [24]; therefore, $48 \mathrm{~h}$ was chosen for the long-term treatment.
Approximately 1500 protein spots were detected by Coomassie Brilliant Blue staining, and approximately 900 protein spots matched across all the gels. Representative images of the 2D gel maps are shown in Figure 1. Proteins were well separated in both dimensions. The percentage volumes of protein spots in triplicate samples were subjected to statistical analysis, and the protein spots were considered to be differentially expressed if they had a relative volume ratio above the threshold $(>1.5$ fold and $p<0.05$ ) for at least one time point after MeJA treatment. The comparative image analysis of MeJA-treated WT and jin1-9/myc2 mutant plants led to the identification of 30 protein spots that had changed significantly in abundance $(p<0.05)$. Protein spots that contained differentially expressed proteins were excised, trypsin digested, and analyzed by MS analysis. These 30 protein spots were subjected to MS/MS sequencing via MALDI-TOF mass spectrometry, and 27 unique proteins were successfully identified with high confidence by MS analysis and by performing a search against the MASCOT database (Figure 1, Table 1, Additional file 1). These results suggest that both MeJA treatment and the presence of MYC2 are required for the regulation of these 27 proteins.

To confirm whether MeJA is indispensable for the regulation of these 27 proteins, protein profiles of WT and jin1-9/myc2 mutant plants that were mock-treated were compared. Our results demonstrate that, in the absence of MeJA treatment, there are no obvious differences in the expression of these 27 proteins $(<1.5$ fold or $p>0.05)$ between the WT and jin1-9/myc2 mutant plants (Additional file 2). These results suggest that MeJA treatment is essential for the regulation of these proteins. To verify whether MYC2 is required for JAregulated expression of these 27 proteins, the protein profiles of mock-treated jin1-9/myc2 and MeJA-treated jin1-9/myc2 mutant plants were analyzed, and no significant differences $(<1.5$ fold or $p>0.05)$ were observed (Additional file 2). Thus, MYC2 is essential for the varied expression of these proteins, and JA regulates the expression of these 27 proteins in a MYC2-dependent manner. As shown in Table 1, after $6 \mathrm{~h}$ of MeJA treatment, the expression of 19 proteins in jin1-9/myc2 plants changed significantly. The expression of 15 proteins decreased, whereas the expression of 4 proteins increased. The expression of 11 proteins was significantly decreased in jin1-9/myc2 plants that were treated with MeJA for $48 \mathrm{~h}$. These results suggest that MYC2 might predominantly play a positive role in short-term and long-term JA signaling events.

\section{Functional classification of JA-regulated proteins}

Identification of proteins that are differentially expressed due to MeJA treatment and MYC2 expression is an 

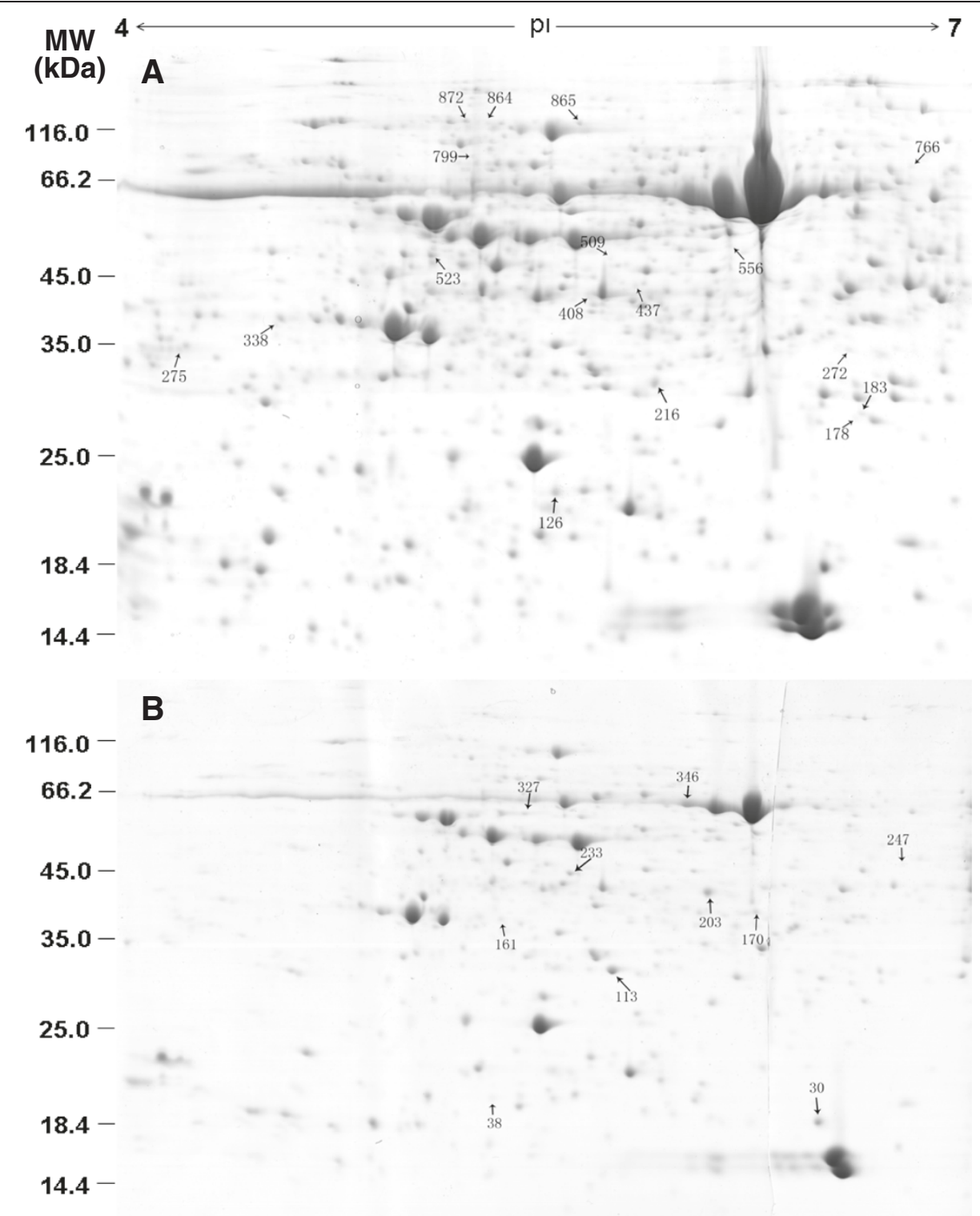

Figure 1 2-DE gel analysis of proteins extracted from the jin 1-9/myc2 mutant. Separation on the first dimension was performed using $1300 \mathrm{\mu g}$ of total soluble proteins using the linear gradient IPG strips with pH 4-7. In the second dimension, 12.5\% SDS-PAGE gels were used, and proteins were visualized using coomassie brilliant blue. Arrows indicate 27 protein spots that changed reproducibly and significantly in MeJAtreated jin 1-9/myc2 mutant plants compared to MeJA-treated wild-type plants. A and B represent 2-DE gels from jin 1-9/myc2 samples treated with $200 \mathrm{mM}$ MeJA for $6 \mathrm{~h}$ and $48 \mathrm{~h}$, respectively. 2-DE experiments were repeated 3 times with independent biological replicates.

important step in understanding JA-regulated MYC2dependent signaling pathways. JA plays a critical role in plant defense against pathogens and insects and modulates the biosynthesis of secondary metabolites, the development of the flower and fertility by regulating the expression of related genes [25]. To further examine the differentially expressed proteins, the identified proteins were grouped according to functional categories based on Gene Ontology and by using the MAPMAN software application. As expected, the identified proteins covered a wide range of molecular functions, including glucosinolate metabolism (22.2\%), stress and defense (33.3\%), photosynthesis $(22.2 \%)$, carbohydrate metabolism (7.4\%), protein folding and degradation (11.1\%), and others (3.7\%) (Table 1, Figure 2). The three largest groups of proteins consisted of 21 proteins, which were associated with photosynthesis, stress and defense, and glucosinolate metabolism.

\section{Glucosinolate metabolism}

Glucosinolates are a group of nitrogen- and sulfurcontaining secondary metabolites that largely exist in the 


\begin{tabular}{|c|c|c|c|c|c|c|c|c|c|c|c|c|c|c|c|}
\hline \multirow[t]{2}{*}{$\begin{array}{l}\text { Spot } \\
\text { No. }^{a}\end{array}$} & \multirow[t]{2}{*}{ Category and name } & \multirow[t]{2}{*}{$\begin{array}{c}\text { gi } \\
\text { Number }\end{array}$} & \multirow[t]{2}{*}{$\begin{array}{l}\text { Exp } \\
\mathrm{pl} / \mathrm{kDa}^{\mathrm{c}}\end{array}$} & \multirow[t]{2}{*}{$\begin{array}{l}\text { Thero } \\
\mathrm{pl} / \mathrm{kDa}^{\mathrm{d}}\end{array}$} & \multirow[t]{2}{*}{ Score $e^{e}$} & \multirow[t]{2}{*}{$\begin{array}{l}\mathrm{SC}^{\mathrm{f}} \\
(\%)\end{array}$} & \multirow[t]{2}{*}{$\mathrm{PN}^{\mathrm{g}}$} & \multirow{2}{*}{$\begin{array}{c}\begin{array}{c}\text { MeJA-Treated } \\
\text { WT 6h }\end{array} \\
\text { Vol\% } \\
(\text { mean } \pm S D)\end{array}$} & \multirow{2}{*}{$\begin{array}{c}\begin{array}{c}\text { MeJA-Treated } \\
\text { jin1-9 } 6 \mathrm{~h}^{\mathrm{h}}\end{array} \\
\text { Vol\% } \\
(\text { mean } \pm \text { SD) }\end{array}$} & \multirow[t]{2}{*}{$\begin{array}{l}\text { Fold } \\
\text { change }\end{array}$} & \multirow[t]{2}{*}{$p$-value } & \multirow{2}{*}{$\begin{array}{c}\begin{array}{c}\text { MeJA-Treated } \\
\text { WT 48h }\end{array} \\
\text { Vol\% } \\
\text { (mean } \pm \text { SD) }\end{array}$} & \multirow{2}{*}{$\begin{array}{c}\begin{array}{c}\text { MeJA-Treated } \\
\text { jin1-9 48h }\end{array} \\
\begin{array}{c}\text { Vol\% } \\
\text { (mean } \pm S D)\end{array}\end{array}$} & \multirow[t]{2}{*}{$\begin{array}{l}\text { Fold } \\
\text { change }\end{array}$} & \multirow[t]{2}{*}{$p$-value } \\
\hline & & & & & & & & & & & & & & & \\
\hline & $\begin{array}{l}\text { Glucosinolate } \\
\text { metabolism }\end{array}$ & & & & & & & & & & & & & & \\
\hline 216 & $\begin{array}{l}\text { glutathione } \\
\text { S-transferase ERD13 } \\
\text { (GSTF10) Neg }\end{array}$ & gi|15224582 & $5.82 / 33.0$ & $5.54 / 29.8$ & 66 & 5 & 2 & $0.11 \pm 0.00$ & $0.17 \pm 0.00$ & 1.51 & 0.00 & $0.17 \pm 0.10$ & $0.09 \pm 0.09$ & -1.88 & 0.37 \\
\hline 327 & $\begin{array}{l}\text { myrosinase-binding- } \\
\text { like protein }\end{array}$ & gi|30684083 & $5.14 / 76.0$ & $5.12 / 48.5$ & 131 & 21 & 6 & $0.05 \pm 0.01$ & $0.04 \pm 0.00$ & -1.15 & 0.23 & $0.08 \pm 0.02$ & $0.04 \pm 0.01$ & -2.10 & 0.02 \\
\hline 509 & sulfotransferase 18 & gi|15221130 & $5.66 / 57.0$ & $5.52 / 40.7$ & 177 & 13 & 4 & $0.01 \pm 0.00$ & $0.00 \pm 0.00$ & -9999 & 0.01 & $0.00 \pm 0.00$ & $0.00 \pm 0.00$ & - & - \\
\hline 523 & $\begin{array}{l}\text { 3-isopropylmalate } \\
\text { dehydrogenase }\end{array}$ & gi|15241338 & $5.04 / 58.0$ & $5.75 / 44.2$ & 88 & 2 & 1 & $0.08 \pm 0.00$ & $0.05 \pm 0.01$ & -1.63 & 0.00 & $0.00 \pm 0.00$ & $0.00 \pm 0.00$ & - & - \\
\hline 556 & amidase 1 & gi|18390964 & $6.08 / 61.0$ & $5.83 / 45.4$ & 152 & 22 & 6 & $0.02 \pm 0.01$ & $0.00 \pm 0.00$ & -9999 & 0.04 & $0.02 \pm 0.03$ & $0.00 \pm 0.00$ & -9999 & 0.19 \\
\hline \multirow[t]{2}{*}{864} & $\begin{array}{l}\text { thioglucoside } \\
\text { glucohydrolase } 1 \\
\text { (TGG1) }\end{array}$ & gi|15809938 & $5.24 / 121.0$ & $5.67 / 61.7$ & 141 & 10 & 4 & $0.02 \pm 0.01$ & $0.00 \pm 0.00$ & -9999 & 0.02 & $0.00 \pm 0.00$ & $0.00 \pm 0.00$ & - & - \\
\hline & Stress and defense & & & & & & & & & & & & & & \\
\hline 113 & $\begin{array}{l}\text { glutathione } \\
\text { S-transferase } \\
\text { DHAR1Pos }\end{array}$ & gi|8778432 & $5.66 / 31.9$ & $6.82 / 50.6$ & 150 & 6 & 2 & $0.12 \pm 0.03$ & $0.07 \pm 0.02$ & -1.75 & 0.05 & $0.48 \pm 0.42$ & $0.31 \pm 0.02$ & -1.56 & 0.00 \\
\hline 161 & putative glyoxalase & gi|9828630 & $5.08 / 38.9$ & $6.97 / 40.3$ & 85 & 12 & 3 & $0.04 \pm 0.02$ & $0.00 \pm 0.00$ & -9999 & 0.02 & $0.05 \pm 0.01$ & $0.02 \pm 0.01$ & -2.22 & 0.01 \\
\hline 183 & $\begin{array}{l}\text { glutathione } \\
\text { S-transferase } \\
\text { (AtGSTF3) }\end{array}$ & gi|497788 & $6.40 / 29.1$ & $5.80 / 23.5$ & 116 & 11 & 2 & $0.03 \pm 0.01$ & $0.00 \pm 0.00$ & -9999 & 0.00 & $0.08 \pm 0.00$ & $0.01 \pm 0.00$ & -14.16 & 0.00 \\
\hline 203 & $\begin{array}{l}\text { putative } \\
\text { arginase }^{\text {Pos }}\end{array}$ & gi|15236635 & $6.01 / 44.0$ & $5.90 / 38.1$ & 163 & 12 & 4 & $0.11 \pm 0.01$ & $0.13 \pm 0.01$ & 1.14 & 0.05 & $0.30 \pm 0.02$ & $0.19 \pm 0.03$ & -1.61 & 0.01 \\
\hline 275 & $\begin{array}{l}\text { HSP20-like } \\
\text { chaperones protein }\end{array}$ & gi|3193303 & $4.17 / 36.0$ & $4.42 / 28.0$ & 103 & 16 & 4 & $0.04 \pm 0.01$ & $0.00 \pm 0.00$ & -9999 & 0.00 & $0.02 \pm 0.01$ & $0.00 \pm 0.00$ & -9999 & 0.09 \\
\hline 338 & $\begin{array}{l}\text { putative plastid- } \\
\text { lipid-associated } \\
\text { protein } 1\end{array}$ & gi|15233357 & $4.52 / 41.0$ & $5.45 / 35.0$ & 161 & 23 & 5 & $0.02 \pm 0.01$ & $0.00 \pm 0.00$ & -9999 & 0.00 & $0.13 \pm 0.08$ & $0.03 \pm 0.03$ & -4.55 & 0.09 \\
\hline 408 & $\begin{array}{l}\text { O-acetylserine (thiol) } \\
\text { lyase B (oasB) }\end{array}$ & gi|15224351 & $5.59 / 46.0$ & $8.13 / 42.0$ & 183 & 29 & 8 & $0.02 \pm 0.00$ & $0.10 \pm 0.01$ & 4.70 & 0.00 & $0.02 \pm 0.01$ & $0.00 \pm 0.00$ & -9999 & 0.12 \\
\hline 437 & $\begin{array}{l}\text { O-acetylserine (thiol) } \\
\text { lyase isoform C } \\
\text { (oasC) }\end{array}$ & gi|6899947 & $5.75 / 49.0$ & $6.96 / 41.5$ & 96 & 12 & 3 & $0.02 \pm 0.01$ & $0.00 \pm 0.00$ & -9999 & 0.01 & $0.00 \pm 0.00$ & $0.00 \pm 0.00$ & - & - \\
\hline 872 & $\begin{array}{l}\text { luminal binding } \\
\text { protein (BiP2) }\end{array}$ & gi|1303695 & $5.16 / 122.0$ & $5.08 / 73.7$ & 165 & 11 & 6 & $0.04 \pm 0.01$ & $0.03 \pm 0.00$ & -1.67 & 0.04 & $0.00 \pm 0.00$ & $0.00 \pm 0.00$ & - & - \\
\hline
\end{tabular}


Table 1 Protein identities and relative changes in their expression between MeJA-treated jin 1-9/myc2 and wild-type plants after $6 \mathrm{~h}$ or $48 \mathrm{~h}$ of MeJA treatment (Continued)

\begin{tabular}{|c|c|c|c|c|c|c|c|c|c|c|c|c|c|c|c|}
\hline & Photosynthesis & & & & & & & & & & & & & & \\
\hline 126 & $\begin{array}{l}\text { chlorophyll } \\
\text { a/b-binding protein }\end{array}$ & gi|13265501 & $5.47 / 23.9$ & $6.52 / 26.1$ & 178 & 9 & 3 & $0.12 \pm 0.01$ & $0.19 \pm 0.01$ & 1.60 & 0.00 & $0.07 \pm 0.00$ & $0.06 \pm 0.00$ & -1.08 & 0.13 \\
\hline 170 & $\begin{array}{l}\text { chloroplast } \\
\text { NAD-MDH }\end{array}$ & gi|3256066 & $6.18 / 39.8$ & $8.48 / 42.6$ & 295 & 14 & 5 & $0.17 \pm 0.11$ & $0.03 \pm 0.03$ & -5.88 & 0.10 & $0.13 \pm 0.01$ & $0.09 \pm 0.02$ & -1.55 & 0.03 \\
\hline 233 & $\begin{array}{l}\text { coproporphyrinogen } \\
\text { III oxidase }\end{array}$ & gi|240254000 & $5.51 / 50.0$ & $6.24 / 44.1$ & 155 & 35 & 9 & $0.07 \pm 0.00$ & $0.07 \pm 0.00$ & -1.02 & 0.14 & $0.10 \pm 0.01$ & $0.06 \pm 0.00$ & -1.62 & 0.01 \\
\hline 247 & $\begin{array}{l}\text { uroporphyrinogen } \\
\text { decarboxylase } 2\end{array}$ & gi|15226690 & $6.72 / 54.0$ & $8.29 / 43.7$ & 517 & 32 & 11 & $0.07 \pm 0.00$ & $0.07 \pm 0.00$ & -1.05 & 0.10 & $0.03 \pm 0.01$ & $0.00 \pm 0.00$ & -9999 & 0.01 \\
\hline 346 & $\begin{array}{l}\text { ribulose bisphosphate } \\
\text { carboxylase }\end{array}$ & gi|1944432 & $5.93 / 81.0$ & $6.12 / 48.0$ & 167 & 16 & 7 & $1.04 \pm 0.68$ & $0.13 \pm 0.09$ & -8.33 & 0.08 & $1.00 \pm 0.26$ & $0.00 \pm 0.00$ & -9999 & 0.00 \\
\hline \multirow[t]{2}{*}{865} & $\begin{array}{l}\text { transketolase-like } \\
\text { protein }\end{array}$ & gi|7329685 & $5.56 / 120.0$ & $5.80 / 81.9$ & 113 & 17 & 8 & $0.08 \pm 0.00$ & $0.15 \pm 0.02$ & 1.84 & 0.01 & $0.00 \pm 0.00$ & $0.00 \pm 0.00$ & - & - \\
\hline & $\begin{array}{l}\text { Carbohydrate } \\
\text { metabolism }\end{array}$ & & & & & & & & & & & & & & \\
\hline 272 & $\begin{array}{l}\text { 3-oxoacyl-[acyl-carrier } \\
\text { protein] reductase } \\
\text { (NADH) }\end{array}$ & gi|15229203 & $6.40 / 36.1$ & $6.12 / 28.2$ & 61 & 9 & 2 & $0.03 \pm 0.01$ & $0.00 \pm 0.00$ & -9999 & 0.00 & $0.03 \pm 0.00$ & $0.03 \pm 0.00$ & -1.31 & 0.05 \\
\hline \multirow[t]{2}{*}{766} & $\begin{array}{l}\text { 2-oxoglutarate } \\
\text { dehydrogenase, } \\
\text { E3 subunit }\end{array}$ & gi|4210334 & $6.40 / 95.0$ & $6.96 / 54.0$ & 137 & 34 & 5 & $0.02 \pm 0.00$ & $0.00 \pm 0.00$ & -9999 & 0.00 & $0.00 \pm 0.00$ & $0.00 \pm 0.00$ & - & - \\
\hline & $\begin{array}{l}\text { Protein synthesis, } \\
\text { folding and } \\
\text { destination }\end{array}$ & & & & & & & & & & & & & & \\
\hline 38 & $\begin{array}{l}405 \text { ribosomal } \\
\text { protein S12-1 }\end{array}$ & gi|15218373 & $5.05 / 20.0$ & $5.38 / 15.7$ & 73 & 22 & 2 & $0.08 \pm 0.01$ & $0.02 \pm 0.00$ & -3.76 & 0.00 & $0.08 \pm 0.01$ & $0.03 \pm 0.01$ & -2.37 & 0.01 \\
\hline 178 & $\begin{array}{l}\text { ATP-dependent Clp } \\
\text { protease proteolytic } \\
\text { subunit } 2\end{array}$ & gi|18420643 & $6.40 / 29.1$ & $6.71 / 26.4$ & 92 & 14 & 3 & $0.02 \pm 0.01$ & $0.00 \pm 0.00$ & -9999 & 0.01 & $0.00 \pm 0.00$ & $0.00 \pm 0.00$ & - & - \\
\hline \multirow[t]{2}{*}{799} & $\begin{array}{l}\text { TCP-1/cpn60 } \\
\text { chaperonin family } \\
\text { protein }\end{array}$ & gi|15231255 & $5.19 / 101.0$ & $5.60 / 63.7$ & 308 & 27 & 12 & $0.01 \pm 0.01$ & $0.00 \pm 0.00$ & -9999 & 0.02 & $0.00 \pm 0.00$ & $0.00 \pm 0.00$ & - & - \\
\hline & other & & & & & & & & & & & & & & \\
\hline 30 & $\begin{array}{l}\text { SRPBCC ligand- } \\
\text { binding domain- } \\
\text { containing protein }\end{array}$ & gi|15236566 & $6.41 / 18.1$ & $5.91 / 17.6$ & 72 & 15 & 2 & $0.12 \pm 0.08$ & $0.11 \pm 0.06$ & -1.08 & 0.89 & $0.34 \pm 0.03$ & $0.00 \pm 0.00$ & -9999 & 0.00 \\
\hline
\end{tabular}

after MeJA treatment. Three treatments were performed. 


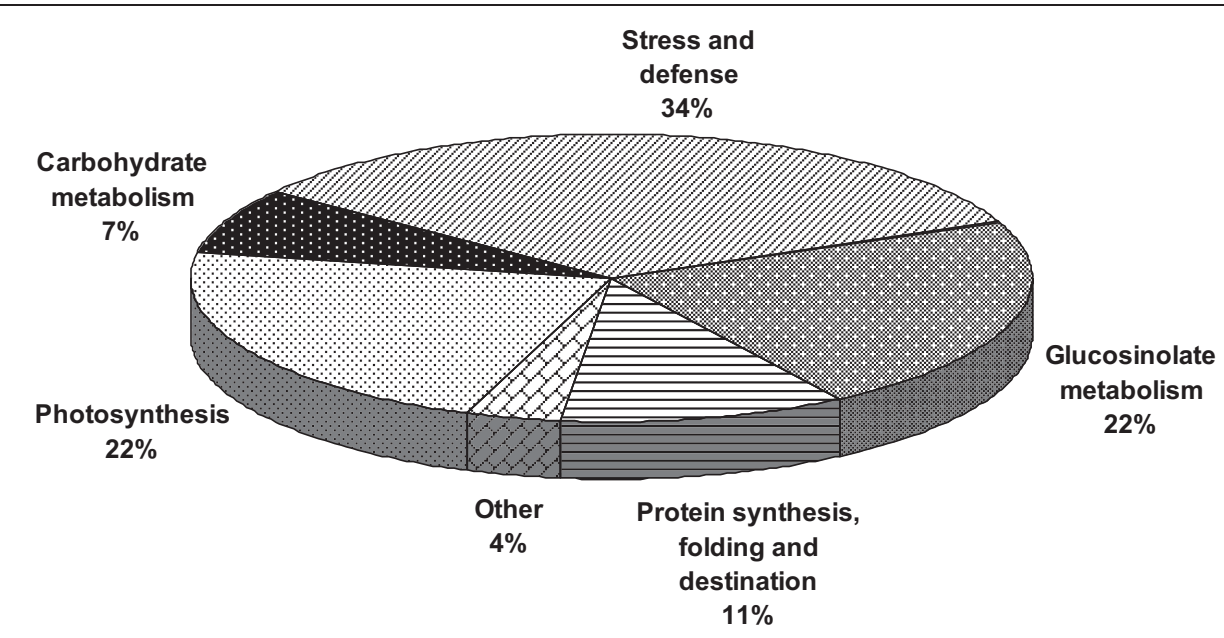

Figure 2 Classification of the identified proteins based on their molecular functions. The pie chart indicates the percent distribution of the MYC2-dependent JA-regulated proteins into their functional classes.

Brassicaceae plants, including Brassica crops and the reference plant, Arabidopsis [26,27]. Glucosinolates are biosynthesized from amino acids and are classified as aliphatic, aromatic, and indolic glucosinolates depending on the origin of the amino acid. The biosynthesis of glucosinolates occurs in three stages, including side-chain elongation of the amino acids, formation of the core structure, and secondary modifications [28], and it is regulated by the JA signaling pathway [29-31].

An increase in glutathione S-transferase ERD13 (GSTF10, spot 216), a protein involved in indolic glucosinolate biosynthesis, was detected in jin1-9/myc2 compared to WT plants after $6 \mathrm{~h}$ of MeJA treatment (Table 1). GSTF10 belongs to the phi class of GSTs and catalyze the biosynthesis of the glucosinolate core structure by adding cysteine during CYP83-catalyzed aldoxime oxidation to form s-alkyl-thiohydroximate in indolic glucosinolate biosysthesis [32,33]. In a previous study, microarray analysis was used to demonstrate that MYC2 negatively regulates JA-dependent indolic glucosinolate biosynthesis [22]. In addition, previous studies showed that GSTF10 was induced by JA/MeJA, and at the mRNA level, the induction was stronger with MeJA in jin1-9/myc2 compared to WT plants [22,34]. Consistent with these observations, our results indicate that GSTF10 is negatively regulated by $\mathrm{MYC} 2$ in response to MeJA treatment. Within the indolic glucosinolate biosynthetic pathway, the indole-3-acetaldoxime pathway overlaps with the IAA biosynthetic pathway in indolic glucosinolateproducing plant species [35]. It has been reported that MeJA increases IAA levels [22,36]. Our result provide additional proof to support the observation that amidase 1 (AMI1, spot 556), a specific indole-3-acetamide amidohydrolase that catalyzes the synthesis of indole-3-acetic acid from indole-3-acetamide [37], is induced in response to
MeJA treatment, and the expression of AMI1 is decreased in jin1-9/myc2 plants compared to WT plants after treatment with MeJA for $6 \mathrm{~h}$. This result indicates that MYC2 is involved in MeJA-induced IAA biosynthesis and might coordinate MeJA-induced IAA and indolic glucosinolate biosynthetic pathways.

As to the proteins involved in aliphatic glucosinolate biosynthesis, we observed that, following MeJA treatment for $6 \mathrm{~h}$, sulfotransferase 18 (SOT18, spot 509) and 3-isopropylmalate dehydrogenase (IPMDH1, spot 523) were expressed at reduced levels in jin1-9/myc2 plants compared to WT plants (Table 1). Sulfotransferases catalyze the sulfation of desulfoglucosinolates, the final step in the biosynthesis of the glucosinolate core structure [38]. In Arabidopsis, three sulfotransferases catalyze a broad range of sulfation reactions for desulfoglucosinolates; however, in a competitive situation, SOT18 (AtST5b) preferentially catalyzes the formation of longchain desulfoglucosinolates derived from methionine [38]. AtST5b has been shown to be induced by JA/MeJA [34], and we speculate that JA signaling might regulate aliphatic glucosinolate biosynthesis through AtST5b in a MYC2-dependent manner. IPMDH is involved in leucine biosynthesis and catalyzes $\mathrm{NAD}^{+}$-dependent oxidation and decarboxylation of 3-isopropylmalate to produce 4methyl-2-oxovalerate [39]. The Arabidopsis genome encodes three IPMDHs (AtIPMDH1, AtIPMDH2, and AtIPMDH3), and among these, AtIPMDH1 plays a key role in methionine chain-elongation for the synthesis of aliphatic glucosinolates [40]. Consistent with the upregulation response of the AtIPMDH1 after MeJA treatment at the transcriptional level [40], our results suggest that AtIPMDH1 is positively regulated by MYC2 in the JA signaling pathway. In contrast to the negative role of MYC2 in JA-dependent indolic glucosinolate biosynthesis 
[22], it appears that MYC2 exhibits opposite effects on the biosynthetic enzymes of indolic and aliphatic glucosinolate pathways, as suggested by the expression of GSTF10, IPMDH1, and ST5b in this study. These results might be due to the homeostatic control of glucosinolate synthesis and crosstalk between indolic and aliphatic glucosinolate biosynthesis $[28,41]$.

The degradation products of glucosinolates play important roles in mediating the interactions of plants with their biotic and abiotic environment (e.g., defense against insects, phytopathogens and sulphur/nitrogen metabolism), which are mediated by myrosinases ( $\beta$-thioglucoside glucohydrolase, TGG). Myrosinases are part of a complex enzyme system that includes myrosinase-binding proteins (MBPs) and myrosinase-associated proteins [42,43]. There are multiple isoenzymes of myrosinase in plants [43], and their expression was demonstrated in restricted tissues $[42,44]$. Capella et al. reported that COI1 controls $M B P$ expression in flowers and dramatically affects myrosinase expression and activity in Arabidopsis [45]. Myrosinase is a COI1-dependent JA-regulated protein, which was demonstrated by 2-DE DIGE analysis [46]. In this study, a decrease in thioglucoside glucohydrolase 1 (TGG1, spot 864) and myrosinase-binding-like protein (spot 327) was observed in jin1-9/myc2 plants compared to WT plants in response to MeJA treatment for $6 \mathrm{~h}$ and $48 \mathrm{~h}$, respectively (Table 1). These results suggest that $\mathrm{MYC} 2$ is a positive regulator of the JA-induced expression of these two proteins. Some myrosinases exhibit pronounced substrate specificity towards glucosinolates (eg. crambe myrosinase from Crambe abysinica is highly specific for epi-progoitrin), and the substrate specificity could be affected by associated factors, including the myrosinase binding protein and myrosinase-associated proteins $[43,47]$. It is possible that the two proteins (spots 864 and 327) are part of the myrosinase system, which targets the functional glucosinolates involved in the MYC2dependent MeJA-induced defense reaction.

Expression changes in five genes that encode the identified glucosinolate metabolism-related proteins were analyzed by performing qRT-PCR analysis. Our results demonstrated that the expression of these five genes was similar and consistent at the mRNA and protein level after $6 \mathrm{~h}$ of MeJA treatment (Figure 3). However, the expression of these genes at the transcriptional level was different from that observed at the protein level after $48 \mathrm{~h}$ of MeJA treatment (Figure 3). This negative proteinmRNA correlation was observed in many other studies [48-50] and indicates that mRNA stability, mRNA splicing, translation, and post-translational events including protein stability and modification are pivotal events in the regulatory mechanisms in biological systems. Thus, proteomic analysis is a direct and efficient approach for studying regulatory mechanisms in biological systems.

\section{Stress and defense}

JA activates plant defense mechanisms in response to biotic and abiotic stresses [51]. It has been reported that jin $1 /$ myc2 plants display increased resistance to fungal and bacterial pathogens $[23,52-54]$. In the event of biotic stresses, such as herbivory insect feeding, the JA signaling pathway generally accelerates glucosinolate metabolism or the degradation of essential amino acids in the herbivore midgut by activating specific amino acid enzymes [55]. Interestingly, we found that despite the accumulation of the different indolic glucosinolate metabolism-related proteins discussed above, the expression of a putative arginase (spot 203, Table 1), the ortholog of the Solanum lycopersicum arginase, which reduces larval weight gain by catabolizing the essential amino acid arginine in the phytophagous insect midgut [55], was reduced in the MeJA-treated jin1-9/myc2 mutant, which is consistent with the results obtained from transcriptomic analysis [22]. The varied expression of arginase and indolic glucosinolate metabolism-related proteins indicates that $\mathrm{MYC} 2$ function is required for JA-mediated insect resistance in Arabidopsis.

JA signaling is important for oxidative stress tolerance. Alteration in the expression of five proteins in response to oxidative stressors was detected, including two cysteine synthases (oasB, spot 408 and oasC, spot 437), two glutathione S-transferases (DHAR1, spot 113 and AtGSTF3, spot 183) and a putative glyoxalase (spot 161) (Table 1). Many abiotic stresses such as drought, heat or salt will cause reactive oxygen species (ROS) production and oxidative damage. In higher plants, glutathione (GSH) plays a considerable role in oxidative stress resistance because it can donate reducing equivalents for scavenging the ROS [56]. Biosynthesis of cysteine is regarded as the rate-limiting step in the production of GSH in plants and is implicated in scavenging ROS and in promoting resistance to abiotic stresses $[57,58]$. The protein level of cysteine synthetase was induced by MeJA, which produced an increase in the total cysteine content $[59,60]$. OasB and oasC have been identified as enzymatically true O-acetylserine (thiol) lyases, which catalyze the second step of cysteine biosynthesis [57,61-63]. When jin1-9/myc2 mutants or WT plants were treated with MeJA for $6 \mathrm{~h}$, the expression of oasB increased, whereas the expression of oas $C$ decreased (Table 1). This indicates that oasB and oas $\mathrm{C}$ play diverse roles in instantly responding to oxidative stress in the JA signaling pathway. In addition to cysteine biosynthesis, plants have glyoxalase systems that include glyoxalase I and glyoxalase II, which provide protection against oxidative damage [64], and a peroxisomal membraneassociated ascorbate-dependent electron transfer system, which consists of monodehydroascorbate reductases (MDAR and DHAR) to protect against oxidative stress. 


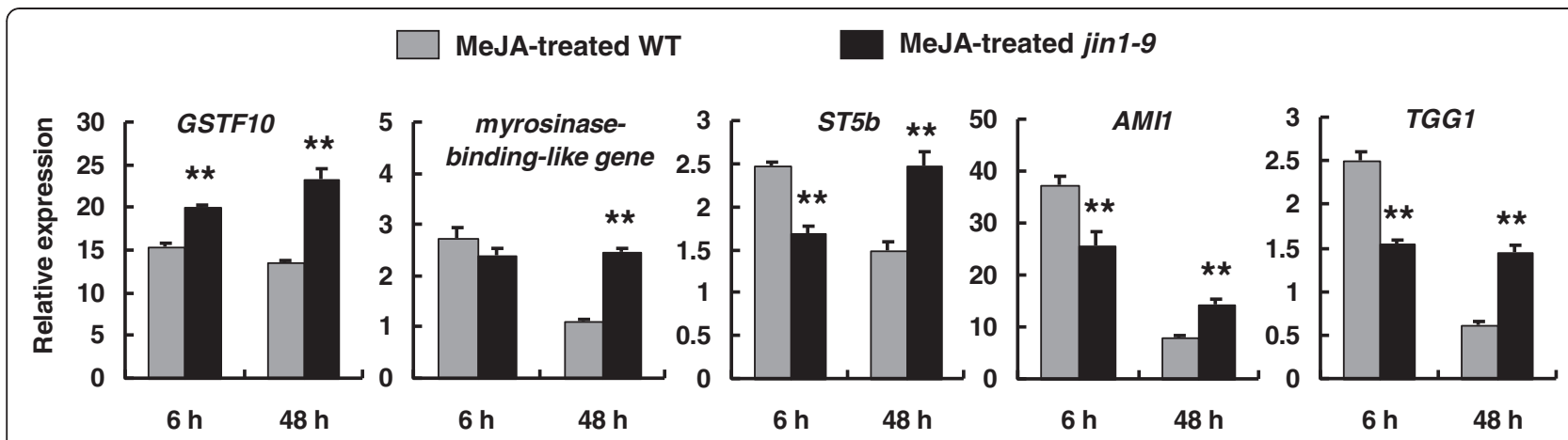

Figure 3 Quantitative real-time PCR analysis of the transcription of genes encoding proteins identified in 2-DE. Data are expressed as relative RNA levels ([mRNA]gene/[mRNA]actin) and are the mean of three biological replicates (> 6 pooled plants each); error bars denote SE. Double stars indicate $p<0.01$ between MeJA-treated jin 1-9/myc2 and wild-type samples.

Treatment with JA increases the de novo synthesis of ascorbate and DHAR and ascorbate peroxidase activity $[3,22,59,65]$. We observed that the induction of putative glyoxalase and DHAR1 by MeJA was reduced in jin1-9/ myc2 plants compared to WT plants, and the induction of DHAR1 is consistent with the results obtained from transcriptomic analysis and with the change in dehydroascorbate reductase in the MeJA-treated coil-1 mutant $[22,46]$. These results suggest that JA-induced dehydroascorbate reductase expression is COI-MYC2dependent. In addition, glutathione S-transferase (AtGSTF3, spot 183), a member of the phi class of GST, which protects plants against oxidative stress [66], is expressed at much lower levels in jin1-9/myc2 plants compared to WT plants following $6 \mathrm{~h}$ and $48 \mathrm{~h}$ of MeJA treatment (Table 1). Overall, the expression of majority of the MeJA-induced proteins associated with multiple protective systems against oxidative stress (spots 113, 161, 183, 437) was reduced in jin1-9/myc2 plants compared to WT plants (Table 1). These results support the positive role of $\mathrm{MYC} 2$ in regulating JA-mediated oxidative stress tolerance [22].

Three other proteins were detected in response to stress. A HSP20-like chaperone protein (spot 275) and a fibrillin precursor protein (putative plastid-lipidassociated protein 1, spot 338) were decreased in jin1-9/ $m y c 2$ plants compared to WT plants after MeJA treatment (Table 1). HSP20 has a protective role against a variety of stressful conditions, including high temperature, high salt, cold, oxidative stress, water stress and toxic metals [67-73]. Fibrillin accumulation enhances the tolerance of photosystem II toward light stress-triggered photoinhibition in Arabidopsis [74]. Our results demonstrated that HSP20 and the fibrillin precursor protein are positively regulated by MYC2 in the JA signaling pathway and therefore might be associated with MYC2-dependent JA-mediated abiotic stress tolerance. In addition, the expression of a luminal binding protein (BiP2, spot 872) was decreased in jin1-9/myc2 plants compared to WT plants after MeJA treatment (Table 1). The expression of $\mathrm{BiP}$ responds to multiple abiotic and biotic stressful conditions, such as fungus infestation, insect attack, nutrient deficiency, drought tolerance, cold stress and MeJA treatment [59,75-77]. The decreased induction of BiP2 in MeJA-treated jin1-9/myc2 plants indicates that the plants might induce $\mathrm{BiP}$ to counteract abiotic and biotic stress in a MYC2-dependent manner in the JA signaling pathway.

\section{Photosynthesis-related proteins}

We identified six photosynthesis-related proteins, including two whose expression was increased and four whose expression was decreased (Table 1 ). With regards to proteins involved in chlorophyll biosynthesis, there was a decrease in the induction of coproporphyrinogen III oxidase (spot 233) and uroporphyrinogen decarboxylase 2 (spot 247) after $48 \mathrm{~h}$ of MeJA treatment in jin1-9/myc2 plants compared to WT plants. Regarding light reactionrelated proteins, the expression of a chlorophyll a/bbinding protein (spot 126) was increased in jin1-9/myc2 plants after $6 \mathrm{~h}$ of MeJA treatment. In addition, the expression of ribulose bisphosphate carboxylase (Rubisco, spot 346), a Calvin cycle-related protein, was decreased in jin1-9/myc2 plants after $48 \mathrm{~h}$ of MeJA treatment, whereas transketolase-like protein (spot 865) was increased in jin1-9/myc 2 plants after $6 \mathrm{~h}$ of MeJA treatment (Table 1). JA has an inhibitory effect on photosynthesis [78] because it represses the expression of photosynthesisrelated genes $[79,80]$. Chlorophyll biosynthesis-related proteins, chlorophyll a/b-binding proteins, and Rubisco proteins were down-regulated by MeJA treatment [59], and treatment with exogenous JA or MeJA caused a decrease in the rate of photosynthetic $\mathrm{CO}_{2}$ fixation, Rubisco activity, and chlorophyll content $[80,81]$. Rubisco is the major enzyme that limits photosynthetic $\mathrm{CO}_{2}$ assimilation and photorespiration [82], while transketolase 
plays a key role in limiting the maximum rate of photosynthesis in the presence of saturating light and $\mathrm{CO}_{2}$ [83]. The increase in the level of chlorophyll a/b-binding protein and transketolase-like protein after $6 \mathrm{~h}$ of MeJA treatment in jin1-9/myc2 plants compared to WT indicates that there is likely a temporary increase in the photosynthetic rate in MeJA-treated jin1-9/myc2 plants. However, the decreased induction of Rubisco, coproporphyrinogen III oxidase, and uroporphyrinogen decarboxylase 2 expression in jin1-9/myc2 plants compared to WT plants suggests that the photosynthetic rate might be decreased in long-term MeJA-treated jin1-9/myc2 plants. Thus, MYC2 could be mediating diverse roles during different stages of the JA signaling pathway. It has been reported that JA-regulated posttranscriptional expression of Rubisco and transketolase requires the inhibitory effect of COI1 [46]. Considering the diverse roles of MYC2 observed in our study, we speculate that JA probably inhibits photosynthesis via the COI1-MYC2 pathway.

\section{Carbohydrate metabolism-related proteins}

It has been reported that MeJA can induce carbohydrate catabolism [59]. During carbohydrate metabolism, carbohydrates are hydrolyzed to monosaccharides, which subsequently undergo glycolysis, the tricarboxylic acid cycle (TCA cycle) and electron transport chain/oxidative phosphorylation under ideal conditions. 3-Oxoacyl[acyl-carrier protein] reductase (NADH, spot 272) and 2-oxoglutarate dehydrogenase, E3 subunit (E3, spot 766), which are commonly involved in the TCA cycle, are decreased in abundance following MeJA treatment in jin1-9/myc2 plants (Table 1). Several proteins involved in the TCA cycle, including the E3, were increased by MeJA treatment [59], and sucrose levels were reduced in MeJA-treated Medicago truncatula cell culture samples [84]. Based on these published observations and our results, we believe that $\mathrm{MYC} 2$ has a positive role in MeJA-induced carbohydrate metabolism.

\section{Protein synthesis, folding, and degradation-related proteins}

MeJA leads to the suppression of total protein and RNA synthesis as well as the activity of nuclear RNA polymerases [85]. 40S ribosomal protein S12-1 (spot 38), TCP-1/cpn60 chaperonin family protein (spot 799) and ATP-dependent Clp protease proteolytic subunit 2 (spot 178) were decreased in MeJA-treated jin1-9/myc2 plants compared to WT plants (Table 1). Protein folding and degradation play a vital role in the regulation of metabolic processes and stress responses. The key ratelimiting enzymes and misfolded/damaged proteins are regulated by different strategies in plants. Correct folding and subsequent assembly into oligomers is required for functional enzymes. Plants can refold the misfolded proteins by chaperonins, which includes the TCP-1/ cpn60 chaperonin protein family [86-88]. It was reported that the TCP-1/cpn60 chaperonin proteins are increased in response to oxygen radicals and bacterial infection and are essential for the correct folding and assembly of polypeptides into oligomeric structures [86,89]. Further, plants can remove the excess or the misfolded/damaged proteins by proteolysis, and most of the targeted intracellular proteolysis is performed by the energy-dependent Clp protease [90]. These results imply that MYC2 is a positive mediator of JA-regulated protein folding and degradation.

\section{Conclusions}

In this study, we applied comparative proteomic approaches to obtain a comprehensive proteomic description of MeJA-treated jin1-9/myc2 and WT plants. Quantitative analysis of 1500 proteins on 2D gels showed that 30 protein spots changed significantly, and of these, 27 were identified by MS analysis, and their functions were determined. The identified proteins were involved in glucosinolate metabolism, stress and defense, photosynthesis, carbohydrate metabolism, protein folding, and degradation, indicating that $\mathrm{MYC} 2$ regulates many of the JA-dependent functions in Arabidopsis. We observed that MYC2 exerts negative and positive effects on indolic glucosinolate biosynthetic enzymes and the myrosinase system, respectively. These results imply that MYC2 is a negative regulator of the JA-dependent accumulation of indolic glucosinolates. Interestingly, we observed that MYC2 exerts opposite effects on the biosynthetic enzymes of indolic and aliphatic glucosinolate pathways, and this is likely due to the homeostatic control of glucosinolate synthesis. This hypothesis needs to be further studied. Most of the MeJA-inducible proteins that are involved in multiple protective systems against oxidative stress were reduced in jin1-9/myc2 plants compared to WT plants, consistent with a positive role for $\mathrm{MYC} 2$ in regulating JA-mediated oxidative stress tolerance. In addition, it was interesting to note that JA-responsive proteins that are implicated in chlorophyll biosynthesis, light reaction, and the Calvin cycle were increased at $6 \mathrm{~h}$ but decreased at $48 \mathrm{~h}$ postMeJA treatment in jin1-9/myc2 plants compared to WT plants. These results imply that MYC2 mediates diverse roles in the modulation of a subset of JA-regulated photosynthesis-related proteins. Moreover, a decrease in the expression of proteins involved in carbohydrate metabolism in $6 \mathrm{~h}$ MeJA-treated jin1-9/myc2 plants compared to WT plants suggests that MYC2 positively regulates MeJA-induced carbohydrate metabolism. A schematic diagram summarizing these findings is shown in Figure 4. Arabidopsis cells perceive JA signals and transmit them to $\mathrm{MYC} 2$ to regulate protein synthesis, 


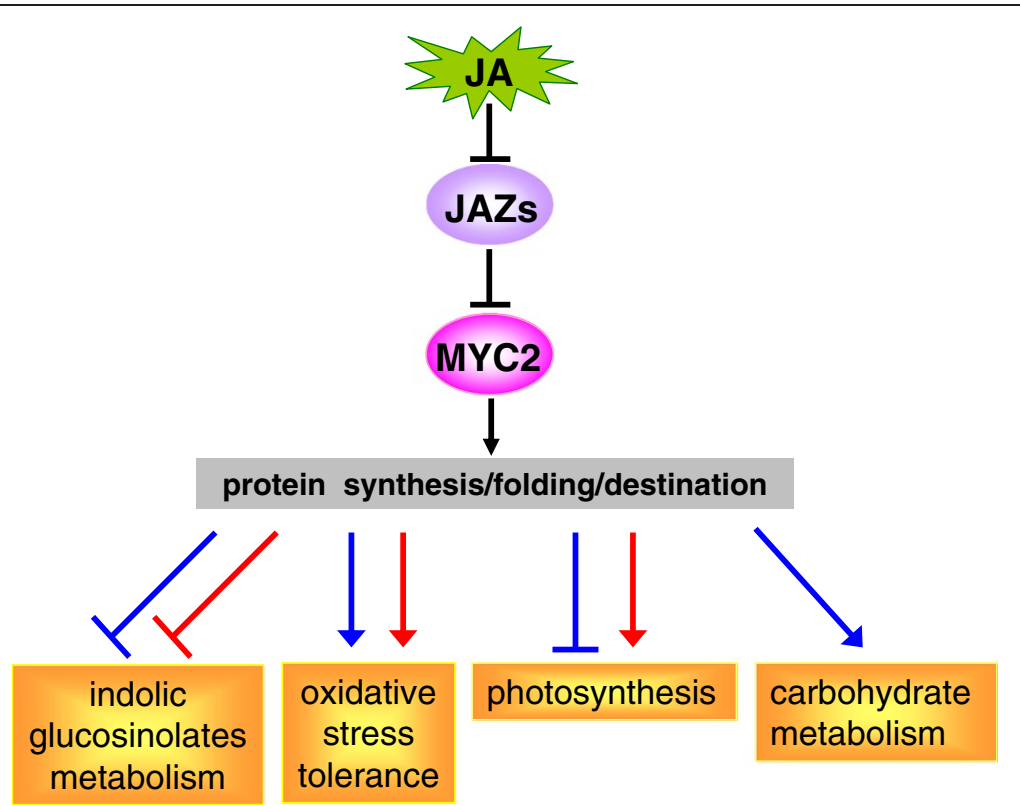

Figure 4 MYC2 differentially regulates different JA-dependent biological process. The role of MYC2 is indicated in blue and red to specify $6 \mathrm{~h}$ and $48 \mathrm{~h} \mathrm{MeJA}$ treatments, respectively. Arrows and blunt arrows indicate positive and negative regulation, respectively.

folding, and degradation; therefore, MYC2 exerts a positive or negative effect on the levels of functional proteins involved in indolic and aliphatic glucosinolate metabolism, oxidative stress tolerance, photosynthesis, and carbohydrate metabolism. This model allows us to further understand the functions of MYC2 in coordinating JA-mediated responses in Arabidopsis.

\section{Materials and methods}

Plant material and treatment

Seeds of Arabidopsis ecotype Columbia (Col-0) and mutant line SALK_017005 (jin1-9) were obtained from the Arabidopsis Biological Resource Center. The location of the T-DNA insertion was verified using a nested PCR approach, and homozygous plants were used in all of the subsequent experiments. Seeds were sown in plastic trays filled with soil and vermiculite mixture (1:1). Seedlings were grown in a growth chamber with an $8 \mathrm{~h}$ light $/ 16 \mathrm{~h}$ dark cycle, $25^{\circ} \mathrm{C} / 20^{\circ} \mathrm{C}$ day/night temperature, $150 \mu \mathrm{mol} \mathrm{m} \mathrm{m}^{-2} \mathrm{~s}^{-1}$ light intensity and a relative humidity of $60 \%$. Two-week-old seedlings (normally with six leaves) were then transferred to hydroponic culture. Fresh half-strength Murashige and Skoog (MS) medium [91] was added every 3 days. Seven days after transfer to hydroponic medium, the seedlings were treated with $200 \mu \mathrm{M}$ MeJA by adding $4 \mathrm{mM}$ stock solution of MeJA (also containing $2 \%$ of ethanol and $0.06 \%$ of Tween 20) or an equal volume of ethanol and Tween-20 to serve as mock controls, according to the protocol of Shan et al. [46]. Leaf samples were directly harvested into liquid nitrogen after $6 \mathrm{~h}$ and $48 \mathrm{~h}$ of treatment.

\section{Protein extraction}

Approximately $1 \mathrm{~g}$ of fresh leaves was harvested from control and $200 \mu \mathrm{M}$ MeJA-treated Col-0 and jin1-9/ $m y c 2$ mutants and ground into fine powder in liquid nitrogen. The powder was precipitated in a $10 \%(\mathrm{w} / \mathrm{v})$ TCA and acetone solution containing $0.07 \%(\mathrm{v} / \mathrm{v}) \beta$ mercaptoethanol at $-20^{\circ} \mathrm{C}$ for at least $2 \mathrm{~h}$. The mixture was centrifuged at $40,000 \mathrm{~g}$ at $4^{\circ} \mathrm{C}$ for $1 \mathrm{~h}$, and the precipitates were washed with cold acetone that contained $0.07 \%$ (v/v) $\beta$-mercaptoethanol, $1 \mathrm{mM}$ phenylmethylsulfonyl fluoride (PMSF), and $2 \mathrm{mM}$ EDTA. Pellets were dried by vacuum centrifugation and dissolved in $7 \mathrm{M}$ urea, $2 \mathrm{M}$ thiourea, 4\% (w/v) cholamidopropyl CHAPS, $20 \mathrm{mM}$ dithiothreitol (DTT), 2\% (v/v) pharmalyte 4-7 (Amersham Pharmacia Biotech, Uppsala, Sweden), and $1 \%(\mathrm{v} / \mathrm{v})$ proteinase inhibitor (Amersham Pharmacia Biotech) at room temperature for $1 \mathrm{~h}$ before being centrifuged at 40,000 g at $4^{\circ} \mathrm{C}$ for $1 \mathrm{~h}$. The supernatant was collected, and the protein concentration was determined using the 2-D Quant kit (GE Healthcare, USA) using BSA as a standard. Samples were frozen in liquid nitrogen and kept at $-80^{\circ} \mathrm{C}$ until further use.

\section{2-DE and data analysis}

Immobiline Dry Strips ( $\mathrm{pH}$ 4-7 linear, $24 \mathrm{~cm}$ long) were run at $30 \mathrm{~V}$ for $8 \mathrm{~h}, 50 \mathrm{~V}$ for $4 \mathrm{~h}, 100 \mathrm{~V}$ for $1 \mathrm{~h}, 300 \mathrm{~V}$ for $1 \mathrm{~h}, 500 \mathrm{~V}$ for $1 \mathrm{~h}, 1,000 \mathrm{~V}$ for $1 \mathrm{~h}$, and $8,000 \mathrm{~V}$ for $12 \mathrm{~h}$ using the hydration buffer (8 M urea, 2\% CHAPS, $20 \mathrm{mM}$ DTT) containing $0.6 \% \mathrm{v} / \mathrm{v}$ IPG buffer. SDSPAGE was performed using $12.5 \%$ polyacrylamide gels without a stacking gel. Proteins were visualized by 
Coomassie Brilliant Blue R250 staining, and gel images were acquired using an ImageScanner (GE Healthcare). Image analysis was performed with ImageMaster 2D Platinum Software Version 7.0 (Amersham Biosciences, Piscataway, NJ). In order to obtain reliable results from 2-DE images, protein samples were always prepared in triplicate. After automated detection and matching, manual editing was carried out to correct the mismatched and unmatched spots. Spots were considered reproducible if they appeared well-resolved in the three biological replicates. For each spot that matched, a measurement was carried out for each biological replicate, and normalized volumes were computed using the software's total spot volume normalization procedure. The normalized volume of each spot was assumed to represent its expression abundance. The criteria used to define significant differences when analyzing parallel spots between groups with two-way ANOVA included a $p<0.05$ and an abundance ratio of at least 1.5.

\section{In-gel digestion and protein identification}

Protein digestion was performed as described previously [59]. For MALDI-TOF/TOF MS analysis, tryptic peptides were desalted with C18 Ziptips (Millipore) and spotted onto a MALDI plate by mixing $1: 1$ with the matrix solution $(10 \mathrm{mg} / \mathrm{mL} \mathrm{CHCA}$ in $60 \% \mathrm{ACN}$ and $0.1 \%$ TFA). MS/MS spectra were acquired using a 4700 MALDI-TOF/TOF mass spectrometer (Applied Biosystems/MDS Sciex, USA). The peptide MS/MS spectra were searched against NCBI non-redundant fasta database $(8,224,370$ entries, downloaded on April 14, 2009) using the Mascot search engine (http://www. matrixscience.com). Mascot was set up to search green plants only, assume trypsin digestion and allow for one miscleavage. The mass tolerance for both parent ion and fragment ion mass was set to be $0.3 \mathrm{Da}$. Iodoacetamide derivatization of Cys, deamidation of Asn and Gln, and oxidation of Met are specified as variable modifications. Unambiguous identification was performed based on the number of peptides obtained, sequence coverage, MASCOT mowse score and the quality of MS/MS spectra.

\section{Quantitative real-time PCR (qRT-PCR)}

The total RNA and qRT-PCR experiments were performed according to Guo et al. [92]. Reverse transcription was performed using the PrimeScript RT reagent Kit (TaKaRa, China). Triplicate quantitative assays were performed with $1 \mu \mathrm{L}$ of cDNA (1:10 dilution) and the SYBR Green Master mix (TaKaRa) using an ABI 7500 sequence detection system (Applied Biosystems, USA). RNA expression was calculated based on a relative standard curve representing 5-fold dilutions of cDNA. The amplification of ACTIN2 was used as an internal control and to normalize the data. The details of primers are listed in Additional file 3. The data analysis was performed using three technical replicates from one biological sample. Similar results were obtained with two other biological replicates.

\section{Additional files}

Additional file 1: Peptide sequences and observed $\mathrm{m} / \mathrm{z}$ of the identified proteins in MALDI-TOF/TOF mass spectrometry analysis.

Additional file 2: Protein identities and changes in their expression in jin 1-9/myc2 plants compared to wild-type plants after $6 \mathrm{~h} / 48 \mathrm{~h}$ of mock treatment and between untreated jin 1-9/myc2 and wild-type plant.

Additional file 3: Sequences of the primers used for quantitative real-time PCR.

\section{Abbreviations}

2-DE: Two-dimensional gel electrophoresis; AMI1: Amidase 1; Arabidopsis: Arabidopsis thaliana; bHLH: Basic helix-loop-helix; COI1: CORONATINE-INSENSITIVE1; DTT: Dithiothreitol; E3: 2-oxoglutarate dehydrogenase, E3 subunit; GSH: Glutathione; GSTF10: Glutathione Stransferase ERD13; JA: Jasmonate; JAZ: JA ZIM-domain; JIN1: JASMONATEINSENSITIVE1; MALDI: Matrix-assisted laser desorption/ionization; MBP: Myrosinase-binding protein; MeJA: Methyl jasmonate; MS: Murashige and Skoog; PMSF: Phenylmethylsulfonyl fluoride; qRT-PCR: Quantitative realtime PCR; ROS: Reactive oxygen species; Rubisco: Ribulose bisphosphate carboxylase; TCA cycle: Tricarboxylic acid cycle; TF: Transcription factor; TGG: Thioglucoside glucohydrolase; TOF: Time-of-flight; WT: Wild type.

\section{Competing interests}

The authors declare that they have no competing interests.

\section{Authors' contributions}

JG conceived the study, prepared the samples, performed the QRT-PCR analysis and drafted the manuscript; QP performed the experiments and data acquisition and drafted the manuscript; LW, PY and NL assisted in performing the experiments; $X Y$ contributed to the overall design of this study. JG, QP and XY read and approved the final manuscript.

\section{Acknowledgements}

This work was supported by the National Natural Science Foundation of China (No. 31070351), the China Postdoctoral Science Foundation (No. 20100480963), the Postdoctoral Foundation of Heilongjiang Province of China (No. LBH-Z10278) and the Fundamental Research Funds for the Central Universities (No. DL09BA25).

\section{Author details}

${ }^{1}$ College of Life and Environmental Science, Wenzhou University, Wenzhou 325035, China. ${ }^{2}$ Alkali Soil Natural Environmental Science Center; Key Laboratory of Saline-alkali Vegetation Ecology Restoration in Oil Field, Ministry of Education, Northeast Forestry University, Harbin 150040, China.

Received: 18 June 2012 Accepted: 18 September 2012

Published: 25 September 2012

\section{References}

1. Feys BJF, Benedetti CE, Penfold CN, Turner JG: Arabidopsis mutants selected for resistance to the phytotoxin coronatine are male sterile, insensitive to methyl jasmonate, and resistant to a bacterial pathogen. Plant Cell 1994, 6:751-759.

2. He Y, Fukushige H, Hildebrand DF, Gan S: Evidence supporting a role of jasmonic acid in Arabidopsis leaf senescence. Plant Physiol 2002, 128:876-884.

3. Sasaki-Sekimoto Y, Taki N, Obayashi T, Aono M, Matsumoto F, Sakurai N, Suzuki H, Hirai MY, Noji M, Saito K, et al: Coordinated activation of metabolic pathways for antioxidants and defence compounds by jasmonates and their roles in stress tolerance in Arabidopsis. Plant J 2005, 44:653-668 
4. Shan X, Zhang Y, Peng W, Wang Z, Xie D: Molecular mechanism for jasmonate-induction of anthocyanin accumulation in Arabidopsis. J Exp Bot 2009, 60:3849-3860

5. Wasternack C: Jasmonates: an update on biosynthesis, signal transduction and action in plant stress response, growth and development. Ann Bot (Lond) 2007, 100:681-697.

6. Yan J, Zhang C, Gu M, Bai Z, Zhang W, Qi T, Cheng Z, Peng W, Luo H, Nan F, et al: The Arabidopsis CORONATINE INSENSITIVE1 protein is a jasmonate receptor. Plant Cell 2009, 21:2220-2236.

7. Xie DX, Feys BF, James S, Nieto-Rostro M, Turner JG: COI1: An Arabidopsis gene required for jasmonate-regulated defense and fertility. Science 1998, 280:1091-1094.

8. Devoto A, Ellis C, Magusin A, Chang HS, Chilcott C, Zhu T, Turner JG: Expression profiling reveals $\mathrm{COI} 1$ to be a key regulator of genes involved in wound- and methyl jasmonate-induced secondary metabolism, defence, and hormone interactions. Plant Mol Biol 2005, 58:497-513.

9. Xu L, Liu F, Lechner E, Genschik P, Crosby WL, Ma H, Peng W, Huang D, Xie D: The SCF(COI1) ubiquitin-ligase complexes are required for jasmonate response in Arabidopsis. Plant Cell 2002, 14:1919-1935.

10. Wang Z, Cao G, Wang X, Miao J, Liu X, Chen Z, Qu LJ, Gu H: Identification and characterization of COI1-dependent transcription factor genes involved in JA-mediated response to wounding in Arabidopsis plants. Plant Cell Rep 2008, 27:125-135.

11. Chini A, Fonseca S, Fernandez G, Adie B, Chico JM, Lorenzo O, García-Casado G, López-Vidriero I, Lozano FM, Ponce MR, et al: The JAZ family of repressors is the missing link in jasmonate signalling. Nature 2007, 448:666-671.

12. Chung HS, Howe GA: A critical role for the TIFY motif in repression of jasmonate signaling by a stabilized splice variant of the JASMONATE ZIM-domain protein JAZ10 in Arabidopsis. Plant Cell 2009, 21:131-145.

13. Chung HS, Koo AJK, Gao X, Jayany S, Thines B, Jones AD, Howe GA: Regulation and function of Arabidopsis JASMONATE ZIM-domain genes in response to wounding and herbivory. Plant Physiol 2008, 146:952-964.

14. Thines B, Katsir L, Melotto M, Niu Y, Mandaokar A, Liu G, Nomura K, He SY, Howe GA, Browse J: JAZ repressor proteins are targets of the SCF (COI1) complex during jasmonate signalling. Nature 2007, 448:661-665.

15. Vanholme B, Grunewald W, Bateman A, Kohchi T, Gheysen G: The tify family previously known as ZIM. Trends Plant Sci 2007, 12:239-244.

16. Yan Y, Stolz S, Chetelat A, Reymond P, Pagni M, Dubugnon L, Farmer EE: A downstream mediator in the growth repression limb of the jasmonate pathway. Plant Cell 2007, 19:2470-2483.

17. Sheard LB, Tan X, Mao H, Withers J, Ben-Nissan G, Hinds TR, Kobayashi Y, Hsu FF, Sharon M, Browse J, et al: Jasmonate perception by inositolphosphate-potentiated COI1-JAZ co-receptor. Nature 2010, 468:400-405.

18. Cheng Z, Sun L, Qi T, Zhang B, Peng W, Liu Y, Xie D: The bHLH transcription factor MYC3 interacts with the jasmonate ZIM-domain proteins to mediate jasmonate response in Arabidopsis. Mol Plant 2011, 4:279-288.

19. Fernández-Calvo P, Chini A, Fernández-Barbero G, Chico JM, GimenezIbanez S, Geerinck J, Eeckhout D, Schweizer F, Godoy M, Franco-Zorrilla JM, et al: The Arabidopsis bHLH transcription factors MYC3 and MYC4 are targets of JAZ repressors and act additively with MYC2 in the activation of jasmonate resoponses. Plant Cell 2011, 23:701-715.

20. Niu Y, Figueroa P, Browse J: Characterization of JAZ-interacting bHLH transcription factors that regulate jasmonate responses in Arabidopsis. $J$ Exp Bot 2011, 62:2143-2154

21. Berger $S$, Bell E, Mullet JE: Two methyl jasmonate-insensitive mutants show altered expression of AtVSP in response to methyl jasmonate and wounding. Plant Physiol 1996, 111:525-531.

22. Dombrecht B, Xue GP, Sprague SJ, Kirkegaard JA, Ross JJ, Reid JB, Fitt GP, Sewelam N, Schenk PM, Manners JM, et al: MYC2 differentially modulates diverse jasmonate-dependent functions in Arabidopsis. Plant Cell 2007, 19:2225-2245

23. Lorenzo O, Chico JM, Sanchez-Serrano JJ, Solano R: JASMONATEINSENSITIVE1 encodes a MYC transcription factor essential to discriminate between different jasmonate-regulated defense responses in Arabidopsis. Plant Cell 2004, 16:1938-1950.

24. Gygi SP, Rochon Y, Franza BR, Aebersold R: Correlation between protein and mRNA abundance in yeast. Mol Cell Biol 1999, 19:1720-1730.

25. Browse J: Jasmonate passes muster: a receptor and targets for the defense hormone. Annu Rev Plant Biol 2009, 60:183-205.

26. Yan X, Chen S: Regulation of plant glucosinolate metabolism. Planta 2007, 226:1343-1352.
27. Wittstock U, Halkier BA: Glucosinolate research in the Arabidopsis era Trends Plant Sci 2002, 7:263-270.

28. Grubb CD, Abel S: Glucosinolate metabolism and its control. Trends Plant Sci 2006, 11:89-100.

29. Cipollini DF, Sipe ML: Jasmonic acid treatment and mammalian herbivory differentially affect chemical defenses and growth of wild mustard (Brassica kaber). Chemoecology 2001, 11:137-143.

30. Doughty KJ, Kiddle GA, Pye BJ, Wallsgrove RM, Pickett JA: Selective induction of glucosinolates in oilseed rape leaves by methyl jasmonate. Phytochemistry 1995, 38:347-350.

31. Kliebenstein DJ, Figuth A, Mitchell-Olds T: Genetic architecture of plastic methyl jasmonate responses in Arabidopsis thaliana. Genetics 2002, 161:1685-1696.

32. Wentzell AM, Rowe HC, Hansen BG, Ticconi C, Halkier BA, Kliebenstein DJ: Linking metabolic QTLs with network and cis-eQTLs controlling biosynthetic pathways. PloS Genet 2007, 3:1687-1701.

33. Hirai MY, Klein M, Fujikawa Y, Yano M, Goodenowe DB, Yamazaki Y, Kanaya S, Nakamura Y, Kitayama M, Suzuki H, et al: Elucidation of gene-to-gene and metabolite-to-gene networks in Arabidopsis by integration of metabolomics and transcriptomics. J Bio/ Chem 2005, 280:25590-25595.

34. Jung C, Lyou SH, Yeu S, Kim MA, Rhee S, Kim M, Lee JS, Choi YD, Cheong J-J: Microarray-based screening of jasmonate-responsive genes in Arabidopsis thaliana. Plant Cell Rep 2007, 26:1053-1063.

35. Normanly J: Approaching cellular and molecular resolution of Auxin biosynthesis and metabolism. Cold Spring Harb Perspect Biol 2010, 2:a001594

36. Sun J, Xu Y, Ye S, Jiang H, Chen Q, Liu F, Zhou W, Chen R, Li X, Tietz O, et al: Arabidopsis ASA1 is important for jasmonate-mediated regulation of Auxin biosynthesis and transport during lateral root formation. Plant Cell 2009, 21:1495-1511.

37. Neu D, Lehmann T, Elleuche S, Pollmann S: Arabidopsis amidase 1, a member of the amidase signature family. FEBS J 2007, 274:3440-3451.

38. Piotrowski M, Schemenewitz A, Lopukhina A, Müller A, Janowitz T, Weiler EW, Oecking C: Desulfoglucosinolate sulfotransferases from Arabidopsis thaliana catalyze the final step in the biosynthesis of the glucosinolate core structure. J Biol Chem 2004, 279:50717-50725.

39. Drevland RM, Waheed A, Graham DE: Enzymology and evolution of the pyruvate pathway to 2-oxobutyrate in Methanocaldococcus jannaschii. J Bacteriol 2007, 189:4391-4400.

40. He Y, Mawhinney TP, Preuss ML, Schroeder AC, Chen B, Abraham L, Jez JM, Chen $S$ : A redox-active isopropylmalate dehydrogenase functions in the biosynthesis of glucosinolates and leucine in Arabidopsis. Plant J 2009, 60:679-690.

41. Beekwilder J, van Leeuwen W, van Dam NM, Bertossi M, Grandi V, Mizzi L, Soloviev M, Szabados L, Molthoff JW, Schipper B, et al: The impact of the absence of aliphatic glucosinolates on insect herbivory in Arabidopsis. PLoS One 2008, 3(4):e2068.

42. Barth C, Jander G: Arabidopsis myrosinases TGG1 and TGG2 have redundant function in glucosinolate breakdown and insect defense. Plant J 2006, 46:549-562

43. Bones AM, Rossiter JT: The myrosinase-glucosinolate system. - an innate defense system in plants. Physiol Plantarum 1996, 97:194-208.

44. Ueda H, Nishiyama C, Shimada T, Koumoto Y, Hayashi Y, Kondo M, Takahashi T, Ohtomo I, Nishimura M, Hara-Nishimura I: AtVAM3 is required for normal specification of idioblasts, myrosin cells. Plant Cell Physiol 2006, 47:164-175.

45. Capella AN, Menossi M, Arruda P, Benedetti CE: COI1 affects myrosinase activity and controls the expression of two flower-specific myrosinasebinding protein homologues in Arabidopsis. Planta 2001, 213:691-699.

46. Shan X, Wang J, Chua L, Jiang D, Peng W, Xie D: The role of Arabidopsis rubisco activase in jasmonate-induced leaf senescence. Plant Physiol 2011, 155:751-764.

47. Bernardi R, Finiguerra MG, Rossi AA, Sandro P: Isolation and biochemical characterization of a basic myrosinase from ripe Crambe abyssinica seeds, highly specific for epi-progoitrin. J Agric Food Chem 2003, 51:2737-2744.

48. Chen G, Gharib TG, Huang CC, Taylor JM, Misek DE, Kardia SL, Giordano TJ, lannettoni MD, Orringer MB, Hanash SM, et al: Discordant protein and mRNA expression in lung adenocarcinomas. Mol Cell Proteomics 2002, 1:304-313

49. Yan SP, Zhang QY, Tang ZC, Su WA, Sun WN: Comparative proteomic analysis provides new insights into chilling stress responses in rice. Mol Cell Proteomics 2006, 5:484-496.

50. Zhao PM, Wang LL, Han LB, Wang J, Yao Y, Wang HY, Du XM, Luo YM Xia GX: Proteomic identification of differentially expressed proteins 
in the Ligon lintless mutant of upland cotton (Gossypium hirsutum L.). J Proteome Res 2010, 9:1076-1087.

51. Wasternack C, Parthier B: Jasmonate-signalled plant gene expression. Trends Plant Sci 1997, 2:302-307.

52. Anderson JP, Badruzsaufari E, Schenk PM, Manners JM, Desmond OJ, Ehlert C, Maclean DJ, Ebert PR, Kazan K: Antagonistic interaction between abscisic acid and jasmonate-ethylene signaling pathways modulates defense gene expression and disease resistance in Arabidopsis. Plant Cell 2004, 16:3460-3479.

53. Laurie-Berry N, Joardar V, Street IH, Kunkel BN: The Arabidopsis thaliana JASMONATE INSENSITIVE 1 gene is required for suppression of salicylic acid-dependent defenses during infection by Pseudomonas syringae. Mol Plant Microbe Interact 2006, 19:789-800.

54. Nickstadt A, Thomma BPHJ, Feussner I, Kangasjarvi J, Zeier J, Loeffler C, Scheel D, Berger S: The jasmonate-insensitive mutant jin 1 shows increased resistance to biotrophic as well as necrotrophic pathogens. Mol Plant Pathol 2004, 5:425-434.

55. Chen H, Wilkerson CG, Kuchar JA, Phinney BS, Howe GA: Jasmonateinducible plant enzymes degrade essential amino acids in the herbivore midgut. PNAS 2005, 102:19237-19242.

56. May MJ, Vernoux T, Leaver C, Van Montagu M, Inzé D: Glutathione homeostasis in plants: implications for environmental sensing and plant development. J Exp Bot 1998, 49:649-667.

57. Hell R, Wirtz M: Metabolism of cysteine in plants and phototrophic bacteria In Sulfur metabolism in phototrophic organisms. 27th edition. Edited by Hell R, Dahl C, Knaff D, Leustek T. Dordrecht: Springer Netherlands; 2008:59-91.

58. Youssefian S, Nakamura M, Orudgev E, Kondo N: Increased cysteine biosynthesis capacity of transgenic tobacco overexpressing an OAcetylserine(thiol) lyase modifies plant responses to oxidative stress. Plant Physiol 2001, 126:1001-1011.

59. Chen Y, Pang Q, Dai S, Wang Y, Chen S, Yan X: Proteomic identification of differentially expressed proteins in Arabidopsis in response to methyl jasmonate. J Plant Physiol 2011, 168:995-1008.

60. Ali BM, Hahn EJ, Paek KY: Methyl jasmonate and salicylic acid induced oxidative stress and accumulation of phenolics in Panax ginseng bioreactor root suspension cultures. Molecules 2007, 12:607-621.

61. Heeg C, Kruse C, Jost R, Gutensohn M, Ruppert T, Wirtz M, Hell R: Analysis of the Arabidopsis O-acetylserine(thiol) lyase gene family demonstrates compartment-specific differences in the regulation of cysteine synthesis. Plant Cell 2008, 20:168-185.

62. Wirtz M, Droux M, Hell R: O-Acetylserine (thiol) lyase: an enigmatic enzyme of plant cysteine biosynthesis revisited in Arabidopsis thaliana. J Exp Bot 2004, 55:1785-1798.

63. Yamaguchi Y, Nakamura T, Kusano T, Sano H: Three Arabidopsis genes encoding proteins with differential activities for cysteine synthase and $\beta$-cyanoalanine synthase. Plant Cell Physiol 2000, 41:465-476.

64. Hoque MA, Banu MNA, Nakamura Y, Shimoishi Y, Murata Y: Proline and glycinebetaine enhance antioxidant defense and methylglyoxal detoxification systems and reduce $\mathrm{NaCl}$-induced damage in cultured tobacco cells. J Plant Physiol 2008, 165:813-824.

65. Wolucka BA, Goossens A, Inzé D: Methyl jasmonate stimulates the de novo biosynthesis of vitamin C in plant cell suspensions. J Exp Bot 2005, 56:2527-2538.

66. Sappl PG, Carroll AJ, Clifton R, Lister R, Whelan J, Harvey MA, Millar A, Singh KB: The Arabidopsis glutathione transferase gene family displays complex stress regulation and co-silencing multiple genes results in altered metabolic sensitivity to oxidative stress. Plant J 2009, 58:53-68.

67. Banzet N, Richaud C, Deveaux Y, Kazmaier M, Gagnon J, Triantaphylidès C: Accumulation of small heat shock proteins, including mitochondrial HSP22, induced by oxidative stress and adaptive response in tomato cells. Plant J 1998, 13:519-527.

68. Guan JC, Jinn TL, Yeh CH, Feng SP, Chen YM, Lin CY: Characterization of the genomic structures and selective expression profiles of nine class I small heat shock protein genes clustered on two chromosomes in rice (Oryza sativa L.). Plant Mol Biol 2004, 56:795-809.

69. Harrington HM, Alm DM: Interaction of heat and salt shock in cultured tobacco cells. Plant Physiol 1988, 88:618-625.

70. Sabehat A, Lurie S, Weiss D: Expression of small heat-shock proteins at low temperatures.-A possible role in protecting against chilling injuries. Plant Physiol 1998, 117:651-658.
71. Sato Y, Murakami T, Funatsuki H, Matsuba S, Saruyama H, Tanida M: Heat shock-mediated APX gene expression and protection against chilling injury in rice seedlings. J Exp Bot 2001, 52:145-151.

72. Sato Y, Yokoya S: Enhanced tolerance to drought stress in transgenic rice plants overexpressing a small heat-shock protein, sHSP17.7. Plant Cell Rep 2008, 27:329-334.

73. Wollgiehn R, Neumann D: Stress response of tomato cell cultures to toxic metals and heat shock: differences and similarities. J Plant Physiol 1995, $146: 736-742$.

74. Yang Y, Sulpice R, Himmelbach A, Meinhard M, Christmann A, Grill E: Fibrillin expression is regulated by abscisic acid response regulators and is involved in abscisic acid-mediated photoprotection. PNAS 2006, 103:6061-6066.

75. Alvim FC, Carolino SMB, Cascardo JCM, Nunes CC, Martinez CA, Otoni WC, Fontes EPB: Enhanced accumulation of BiP in transgenic plants confers tolerance to water stress. Plant Physiol 2001, 126:1042-1054.

76. Anderson JV, Li QB, Haskell DW, Guy CL: Structural organization of the spinach endoplasmic reticulum-luminal 70-kilodalton heat-shock cognate gene and expression of 70-kilodalton heat-shock genes during cold acclimation. Plant Physiol 1994, 104:1359-1370.

77. Kalinski A, Rowley DL, Loer DS, Foley C, Buta G, Herman EM: Bindingprotein expression is subject to temporal, developmental and stressinduced regulation in terminally differentiated soybean organs. Planto 1995, 195:611-621.

78. Jung S: Effect of chlorophyll reduction in Arabidopsis thaliana by methyl jasmonate or norflurazon on antioxidant systems. Plant Physiol Bioch 2004, 42:225-231.

79. Bunker TW, Koetje DS, Stephenson LC, Creelman RA, Mullet JE, Grimes HD: Sink limitation induces the expression of multiple soybean vegetative lipoxygenase mRNAs while the endogenous jasmonic acid level remains low. Plant Cell 1995, 7:1319-1331.

80. Weidhase RA, Kramell HM, Lehmann J, Liebisch HW, Lerbs W, Parthier B: Methyljasmonate-induced changes in the polypeptide pattern of senescing barley leaf segments. Plant Sci 1987, 51:177-186.

81. Popova LP, Tsonev TD, Vaklinova SG: Changes in some photosynthetic and photorespiratory properties in barley leaves after treatment with jasmonic acid. J Plant Physiol 1988, 132:257-261.

82. Raines CA: Transgenic approaches to manipulate the environmental responses of the $C_{3}$ carbon fixation cycle. Plant Cell Environ 2006, 29:331-339.

83. Henkes U, Sonnewald R, Badur R, Flachmann R, Stitt M: A small decrease of plastid transketolase activity in antisense tobacco transformants has dramatic effects on photosynthesis and phenylpropanoid metabolism. Plant Cell 2001, 13:535-551.

84. Broeckling CD, Huhman DV, Farag MA, Smith JT, May GD, Mendes P, Dixon RA, Sumner LW: Metabolic profiling of Medicago truncatula cell cultures reveals the effects of biotic and abiotic elicitors on metabolism. J Exp Bot 2005, 56:323-336.

85. Ananieva Kl, Ananiev ED: Effect of methyl ester of jasmonaic acid and benzylaminopurine on growth and protein profile of excised cotyledons of Cucurbita pepo (Zucchini). Biol Plantarum 1999, 42:549-557.

86. Prasad TK, Stewart CR: CDNA clones encoding Arabidopsis thaliana and Zea mays mitochondrial chaperonin HSP60 and gene expression during seed germination and heat shock. Plant Mol Biol 1992, 18:873-885.

87. Gatenby AA: Protein folding and chaperonins. Plant Mol Biol 1992, 19:677-687.

88. Fink AL: Chaperone-mediated protein folding. Physiol Rev 1999, 79:425-449.

89. Gor D, Mayfield JE: Cloning and nucleotide sequence of the Brucella abortus groe operon. Biochim Biophys Acta 1992, 1130:120-122.

90. Porankiewicz J, Wang J, Clarke AK: New insights into the ATP-dependent Clp protease: Escherichia coli and beyond. Mol Microbiol 1999, 32:449-458.

91. Murashige T, Skoog F: A revised medium for rapid growth and bioassays with tobacco tissue cultures. Physiol Plantarum 1962, 15:473-497.

92. Guo J, Wang F, Song J, Sun W, Zhang XS: The expression of Orysa, $\mathrm{CycB} 1,1$ is essential for endosperm formation and causes embryo enlargement in rice. Planta 2010, 231:293-303.

doi:10.1186/1477-5956-10-57

Cite this article as: Guo et al:: Proteomic identification of MYC2dependent jasmonate-regulated proteins in Arabidopsis thaliana. Proteome Science 2012 10:57. 